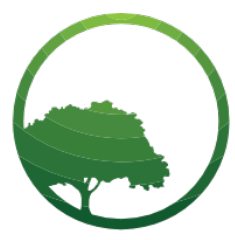

Business \& Social Science IJRBS

\section{Research in Business and Social Science}

IJRBS Vol 8 No 4, ISSN: 2147-4478

Contents available at www.ssbfnet.com/ojs

\title{
Relationship between Financial Ratio and Financial Statement Fraud Risk Moderated by Auditor Quality
}

\section{Tomy Rizky Izzalqurny}

Corresponding Author: Accounting Department, Brawijaya University, Indonesia

ORCID ID: 0000-0002-6198-1952

\section{Bambang Subroto}

Accounting Department, Brawijaya University, Indonesia

\section{Abdul Ghofar}

Accounting Department, Brawijaya University, Indonesia

\begin{abstract}
This study was aimed to prove the research hypothesis that there are effects of financial ratios, which consist of profitability, leverage, and liquidity on the financial statements fraud risk, and the quality of auditors are able to moderate the relationship between financial ratios to financial statements fraud. This study uses a population of manufacturing companies that publish their financial statements on the Indonesian Stock Exchange in 2016-2017 will also be summarized and inferred. This study uses purposive sampling so that the study sample amounted to 275 firm years. The dependent variable uses the financial statements fraud risk with the proxy Dechow F-score. The independent variable in this study consisted of profitability with ROA ratio, leverage using the calculation of the ratio of total liabilities to total assets, and liquidity using the calculation of the ratio of total current assets to current liabilities. The moderating variable in this study is auditor quality as a moderating variable with a dummy variable. The Hypothesis test conducted is using moderated regression analysis (MRA). The results of this study indicate that the financial statements fraud risk is influenced by financial liquidity ratios, while financial ratios of profitability and leverage have not been proven to affect financial report fraud. This study provides a contribution by providing evidence that the quality of auditors can suppress fraudulent actions on financial statements with low profitability. This research provides information to regulators to pay more attention to companies that experience liquidity problems, and become input for regulators to make rules that improve the quality of auditors.
\end{abstract}

Key words: Profitability, Leverage, Liquidity, Audit, Fraud

JEL classification: M41, M42, 016

Submitted: 12.06.2019 - Accepted: 28.06.2019 


\section{Introduction}

Fraud is a common concern for various parties such as company management and regulators. Association of Certified Fraud Examiner (2018: 10) divides the types of fraud into three, consist of assets misappropriation, corruption, and financial statements fraud. The three types of fraud could be a disadvantage to the company, and financial statements fraud has a high median loss. These results indicate the high impact of financial statement fraud and became a serious problem for the market and the economy (Albrecht, et al., 2012: 360). Financial statements fraud in Indonesia also proved to have a high median loss, because most of the median losses were more than 10 billion rupiahs (ACFE Indonesia Chapter, 2017: 15). Moreover, this case was determined with the fraud triangle theory can show because of the pressure of poor financial performance.

Financial statements fraud show from companies that falling on financial difficulties or poor financial performance (Nia, 2015). Poor financial performance can be shown from financial ratios. Kanapickienè and Grundienè (2015) and Dalnial, et al. (2014a) reported that financial ratios have the ability to detect and give the signal which could show fraud in financial statements. Financial ratios such as profitability, liquidity, and leverage, can prove to signal fraudulent actions in financial statements.

Omar, et al. (2014) show that profitability has an effect on the restatement of financial statements because with low profitability it becomes a bad signal to investors and it makes a financial statement fraud because of these pressures. Financial ratios such as liquidity and leverage indicate that companies are increasingly burdened with the debt, companies will be more disposed to record fictitious income and take action to manipulate financial statements to show signals that they are able to pay off their obligations. These actions correspond to the fraud triangle theory because when they are under pressure this fraud action is carried out to resolve these problems.

In addition, when organizations are under pressure from poor financial performance, the managers will try to improve their financial position, even though they commit financial statements fraud (Amoa-Gyarteng, 2014). The negative actions from these managers can be weakened by the existence of good quality auditors. The auditor as an external party has a duty to minimize the occurrence of financial statements fraud by revealing fraudulent actions in the financial statements.

Detection of fraud in financial statements is one of the highest priorities for capital market participants and for other stakeholders because market players such as investors will suffer financial losses when fraud occurs in public companies (Dalnial, et al., 2014b). Fraud detection is one of the auditor's special tasks as reported in ISA 240. An independent audit aims to provide assurance that financial statements are clear of fraud or material errors. Therefore, a huge audit company will provide higher audit quality (Lisic, et al., 2014). According to Salem (2012), the auditors will protect and maintain their reputation and professional integrity to avoid legal fees. Thus in accordance with the fraud triangle theory, qualified auditors will minimize the opportunity for financial statements fraud, so that the pressure relationship symbolized by poor financial ratios against financial statements fraud can be weakened by good quality auditors.

This article aims to prove the current research hypothesis on the financial ratios that influences the profitability, leverage, liquidity on financial statements fraud, and auditor quality which can moderate the relationship between financial ratios toward financial statements fraud. Therefore the structures of this article are as follows: a review of the literature, research methodology, empirical data and analysis, results and discussion, and the latest is a conclusion.

\section{Literature Review}

Theoretically according to the fraud triangle theory, financial statements fraud consists of three components. The theory was based on work by Cressey (1953) shows that there are three elements supported fraudulent actions, that is pressure, opportunity, and rationalization. The pressure is a factor that would make unethical actions caused by financial and non-financial pressures. This pressure could show from the value of financial ratios, such as profitability, leverage, and liquidity. Opportunities can also be minimized with good quality auditors. 


\section{Profitability}

Profitability is a ratio that shows the ability of a company to obtain profits (Van Horne and Warchowich, 2005). According to the fraud triangle theory, if the company gets pressure, such as low profitability, it encourages companies to commit financial statements fraud, so the company provides a positive signal to investors and the other stakeholders. The relationship between profitability and financial statements fraud is shown by several studies including another research of Zainudin and Hashim (2016) in Malaysia between 2007 and 2013, and research by Lisic, et al. (2014) in China, which shows that profitability is negatively related to the level of financial statements fraud. This result has been in line with the fraud triangle theory that the lower the profitability, the more pressure the company will encourage financial report fraud. However, there are several studies that show different results, such as the research by Manurung and Hardika (2015) in Indonesia, Dalnial, et al. (2014a, 2014b) in Malaysia from 2000 to 2011, and Manurung and Hadian (2013) in Indonesia, investigated that profitability has no effect on the actions of financial statements. Moreover, Repousis (2016) reported that in Greece profitability is positively related to financial statements fraud. Based on the theory and previous research, the researcher concludes there is a negative relationship between profitability and the risk of financial statements fraud, because of the lower the profitability, the higher the pressure of investors could increase the risk of financial statements fraud, so the hypothesis using the formula below:

$\mathrm{H} 1$ : There is a negative effect of profitability on the risk of financial statements fraud.

\section{Leverage}

Leverage ratio is a ratio which can show the ability of a company to fulfill the liabilities both short and long term if there is liquidation in the company (Van Horne and Warchowich, 2005). The higher level of leverage following more insolvable that company. According to the fraud triangle theory, when the companies increased a high degree of leverage thus also increased the companies pressure, in the order, it becomes a higher risk of financial statements fraud. This result is in agreement with other studies by Dalnial, et al. (2014a, 2014b), Aghghaleh, et al. (2013), and Dani, et al. (2013) in Malaysia. Different results are reported by Repousis (2016) study in Greece, Nia (2015) on the Tehran Stock Exchange, Manurung and Hardika (2015) on the Indonesia Stock Exchange, Lisic, et al. (2014) in China, and Manurung and Hadian (2013) in Indonesia. Based on the theory and previous research, the higher the leverage, the higher the pressure faced by the company in fulfilling its obligations to creditors so that the higher risk of financial statements fraud, so the hypothesis using the formula below:

$\mathrm{H} 2$ : There is a positive effect of leverage on financial statements fraud.

\section{Liquidity}

Liquidity ratio is a ratio that describes a company's ability to pay off liquidity or the current liabilities, in the order it more able to pay off its current liabilities is considered more liquid, if not like that then it is considered an illiquid (Van Horne and Warchowich, 2005). Based on the fraud triangle theory, the lower company's liquidity following the higher pressure faced by the company and make a higher risk of financial statements fraud. This result is in line with the research by Zainudin and Hashim (2016), and Arshad, et al. (2015) in Malaysia, and in contrast to Dalnial, et al. (2014a, 2014b). Based on the theory and previous research, the researcher concludes there is a negative relationship between liquidity and the risk of financial statements fraud, because the lower the liquidity increasing the higher the creditor's pressure, thus increasing the risk of financial statements fraud, so the hypothesis using the formula below:

H3: There is a negative effect of liquidity on financial statements fraud.

\section{Auditor Quality}

A qualified auditor will reduce the chance of financial statements fraud according to the fraud triangle theory. This result is in line with Suryanto (2016)shows that qualified auditors will reduce audit delay which can minimize the fraud. This result is in agreement with the research by Skousen, et al. (2015) that increasing the quality of auditors with increasing external audit committees and auditor size (Lisic, et al., 2014), will 
weaken the level of financial statements fraud. Nevertheless, there are different results shown by the research of Sharma and Iselin (2012).

Based on theory and previous research, the quality of auditors will weaken the risk of fraudulent actions in all conditions, including in poor financial performance. These results indicate that auditor quality can moderate the relationship between financial performance and the risk of financial statements fraud. The relationship of profitability and liquidity to the financial statements fraud risk will be strengthened by the quality of auditors because qualified auditors will increase their role to minimize the occurrence of fraud in order when profitability and liquidity are low, auditors will be more vigilant so as to strengthen negative relations to financial statements fraud. The relationship of leverage will be weakened from the auditor's quality to the risk of financial statements fraud, because qualified auditors will safeguard the creditor's rights, so that when leverage is high, the auditor will be more vigilant, weakening the positive relationship of leverage to financial statements fraud. Thus a hypothesis is arranged:

$\mathrm{H} 4 \mathrm{a}$ : Audit quality will strengthen the negative relationship between profitability and risk of financial statements fraud.

H4b: Audit quality will weaken the positive relationship between leverage and the risk of financial statements fraud.

H4c: Audit quality will strengthen the negative relationship between liquidity and the risk of financial statements fraud.

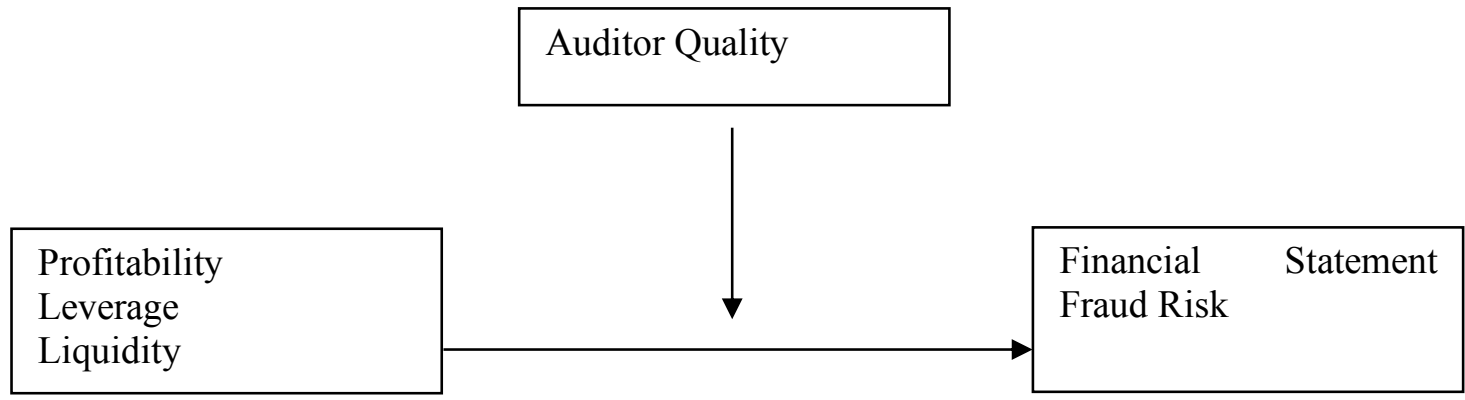

Figure 1: Research Model

\section{Research Methodology}

Population and Samples

This study uses a population of manufacturing companies that publish their financial statements on the Indonesia Stock Exchange in 2016-2017. The samples of this study used purposive sampling and the criteria carried out by researchers:

1. Audited financial statements published on the IDX website and /or company website in 2016 and or 2017.

2. The company has the data needed in the calculation of research.

Based on the population of the company which amounts to 300 firm years, and the research sample is 275 firm years.

\section{Operational Definition and Variable Measurement}

This study uses financial statements fraud risk as to the dependent variable. In this study using a proxy Dechow F-score because of the high level of accuracy according to Aghghaleh, et al. (2016) in Malaysia, the Dechow F-score method was calculated according to the following equation: 
a. $\quad$-score $=\operatorname{Prob}(F F R) / .0037$.

b. Probability $=\frac{e^{\text {Predicted Value }}}{\left(1+e^{\text {predicted Value }}\right)}$

c. Predicted Value $=-7.893+0,790 x$ (rsst_acc) $+2.518 x($ ch_rec $)+$ $1.191 x($ cv_inv $)+1.979 x$ (soft_assets) $+0,17 x($ ch_cs $)+(-0,932) x($ ch_roa $)+1.029 x$ (issue)

d. $\quad$ rsst_acc $=[($ TotalAssetst - Cash\&equivalentst - Investments\&Advances_Othert + InvestmentsatEquityt TotalLiabilitiest - PreferredStockt) - (TotalAssetst-1 - Cash\&equivalents -Investments\&Advances_Othert-1 + InvestmentsatEquityt-1 - TotalLiabilities t-1-PreferredStockt-1)]/[5(TotalAssetst-1 + TotalAssetst)];

ch_rec $=(A R t-A R t-1 t) / .5($ TotalAssetst-1 + TotalAssetst $)$

cv_inv $=($ Inventoryt - Inventoryt-1) /.5(TotalAssetst-1 + TotalAssets $t)$;

soft_assets $=($ TotalAssetst - netPP\&Et - Cash\&equivalentst $) /$ TotalAssetst;

ch_cs $=\{[$ Salest $-(A R t-A R t-1)] /[$ Salest-1 $-($ Art-1-ARt-2) $]\}-1$;

ch_roa $=[$ NetIncomet $/ .5($ TotalAssetst-1 + TotalAssetst $)]-[$ NetIncomet-1/.5(TotalAssetst-2+TotalAssets $t-1)] ;$ and

Issue $=1$ if the company issues long-term debt or ordinary shares in year $t$; 0 for the opposite.

The F-Score reading result is (Hung, et al. (2017)): F-score> 2.45 Very high risk, F-score> 1.85 high risk, Fscore $>=1$ risk above normal level, and F-score $<1$ risk is normal or below.

\section{Independent Variables}

This study used profitability, leverage, and liquidity as to the independent variable. This study calculates profitability with the ROA ratio, which using the calculation of the ratio of total profit after tax to assets. The lower value of profitability ratio it makes pressure by the company and increased gradually the possibility of financial statements fraud. This study calculates leverage by calculating the ratio of total liabilities to total assets. The higher the value of the leverage ratio it makes pressure by the company and increased gradually the possibility of financial statements fraud. This study calculates liquidity by calculating the ratio of total current assets to current liabilities. The lower the value of liquidity ratio, the company will increase more pressure so that was increased gradually the possibility of financial statements fraud.

This study uses auditor quality as a moderating variable. This study uses a dummy variable, so that good auditor quality if Public Accounting Firms affiliated with the Big Four =1, and the auditor's quality is not good if Public Accounting Firms not affiliated with Big Four $=0$.

\section{Analysis Method}

The Hypothesis Test conducted is using moderated regression analysis (MRA), which is by multiplying the independent variables with their moderation (Liana, 2009). Analysis techniques using tiered regression analysis methods. The regression model must pass the classic assumption test, including the normality test, and heteroscedasticity test. Testing was calculated according to the following formula:

$$
\begin{aligned}
& Y=\alpha+\beta 1 . X 1+\beta 2 . X 2+\beta 3 . X 3+€ \\
& \text { (model 1) } \\
& Y=\alpha+\beta 1 . X 1+\beta 2 . X 2+\beta 3 . X 3+\beta 4 . X 4 \\
& Y=\alpha+\beta 1 . X 1+\beta 2 . X 2+\beta 3 . X 3+\beta 4 . X 4+\beta 5 . X 1 . X 4+\beta 6 . X 2 . X 4+\beta 7 . X 3 . X 4+€
\end{aligned}
$$

Description: $Y=$ Risk of financial statements fraud,$\alpha=$ constants, $ß 1-ß 7=$ Regression coefficient, $X 1=$ Profitability, X2 = Leverage, X3 = liquidity, X4 = Audit Quality, $€=$ Error

Model 1 is used to test hypotheses 1,2 and 3, while models 2 and 3 are used to test hypotheses a, b, and c. 


\section{Empirical data and Analysis}

This study has the results of the descriptive analysis shown in table 1 below.

Table 1: Descriptive Statistics

\begin{tabular}{|l|l|l|l|l|}
\hline & Minimum & Maximum & Mean & Std. Deviation \\
\hline FSFR & 0,00 & 1,97 & 0,6152 & 0,39563 \\
\hline Profitability & $-0,55$ & 0,55 & 0,0442 & 0,10985 \\
\hline Leverage & 0,08 & 5,07 & 0,5535 & 0,51821 \\
\hline Liquidity & 0,03 & 15,17 & 2,1612 & 1,80275 \\
\hline Auditor Quality & 0,00 & 1,00 & 0,4073 & 0,49222 \\
\hline
\end{tabular}

$F S F R=$ Risk of financial statements fraud .

The results of the descriptive analysis expressed commonly the financial statements fraud risk of manufacturing companies in Indonesia has a normal risk, because the value below 1 is 0.6152 , with a standard deviation that is below the average indicates that did not have many deviations between values minimum and maximum. The average profitability value is positive, which is 0.0442 , thus indicating that in general manufacturing companies in Indonesia experience profits. The average leverage value shows a positive number and is above 0.5 which is 0.5535 , thus indicating that the majority of funds come from liabilities compared to equity. The average liquidity value is 2.1612 so that on average the manufacturing companies in Indonesia have higher assets than their current debt. Auditor quality shows 0.4073 which means the most manufacturing companies in Indonesia were not audited by public accountants affiliated with big 4.

The results of the regression analysis that has passed the classical assumption test are shown in table 2 .

Table 2: Results of Regression Analysis

\begin{tabular}{|l|l|l|l|l|l|l|}
\hline Model & Variable & B & T & Sig. & Adj. R & Test \\
\hline \multirow{2}{*}{ Model 1 } & Profitability & 0,300 & 2,118 & 0,983 & 0,047 & Hypothesis 1 \\
\cline { 2 - 7 } & Leverage & 0,042 & 1,336 & 0,091 & & Hypothesis 2 \\
\cline { 2 - 7 } & Liquidity & $-0,027$ & $-2,996$ & 0,001 & & Hypothesis 3 \\
\hline Model 2 & Auditor Quality & $-0,100$ & $-3,234$ & 0,001 & 0,079 & Hypothesis 4 \\
\hline Model 3 & MODPROF & $-0,907$ & $-3,230$ & 0,000 & 0,110 & Hypothesis 4a \\
\hline & MODLEV & $-0,178$ & $-1,408$ & 0,080 & & Hypothesis 4b \\
\hline & MODLIK & $-0,008$ & $-0,371$ & 0,355 & & Hypothesis 4c \\
\hline
\end{tabular}

MODPROF = Moderation of profitability and auditor quality, MODLEV = Moderation of leverage and auditor quality, MODLIC = Moderation of liquidity and auditor quality.

As shown in Table 2, hypothesis 1 which tests the negative relationship between profitability and risk of financial statements fraud, the results have a beta value and $t$ of 0.300 and 0.983 with a significance of 0.983 ( $>0.005$ so that it is not significant) so hypothesis 1 is rejected. These results prove that profitability does not negatively affect the risk of financial statements fraud. Testing on hypothesis 2 which tests the positive relationship between leverage and risk of financial statements fraud, shows that beta values and $t$ are 0.042 and 1.336 with a significance of 0.091 (> 0.005 so that it is not significant) so hypothesis 2 is rejected. These results showed that leverage does not have a positive effect on the risk of financial statements fraud. The test on hypothesis 3 which tests the negative relationship between liquidity and risk of financial statements fraud, shows that the beta value and $t$ are -0.027 and -2.996 with a significance of $0.001(<0.005$ so that it is significant) so that hypothesis 3 is accepted. These results examined that liquidity has a negative effect on the risk of financial statements fraud.

The testing of moderation variables is shown by models 2 and 3 in table 2 . Auditor quality is proven to have a negative relationship with the risk of financial statements fraud. These results are shown in model 2 , the value of quality auditors has a beta value and $t$ of $-0,100$ and $-3,234$ with a significance of $0.001(<0,005)$ in order based on statistical testing the qualified auditor will reduce the risk of financial statements fraud. Auditor 
quality testing as a moderating variable was tested by looking at model 3 . These results proved that auditor quality can negatively affect the risk of financial statements fraud.

Hypothesis $4 a$ which examines auditor quality can strengthen the negative relationship between profitability and risk of financial statements fraud, and the results of MODPROF have a beta value and t of -0.907 and 3.230 with a significance of 0,000 ( $<0.005$ so significant) so hypothesis $4 a$ is accepted. These results proved that auditor quality can strengthen the negative relationship between profitability and the risk of financial statements fraud. Hypothesis $4 \mathrm{~b}$ which tests auditor quality can weaken the positive relationship between leverage and risk of financial statements fraud, then the results of MODLEV have a beta value and t of -0.178 and -1.408 with a significance of 0.080 (> 005 so it is not significant) so hypothesis $4 \mathrm{~b}$ is rejected. These results proved that auditor quality cannot weaken the positive relationship between leverage and the risk of financial statements fraud. The $4 \mathrm{c}$ hypothesis that tests auditor quality can strengthen the negative relationship between liquidity and the risk of financial statements fraud, then the MODLIK results have a beta value and $t$ of -0.008 and -0.3371 with a significance of 0.355 (> 005 so that it is not significant) so hypothesis $4 \mathrm{c}$ is rejected. From results also proved the auditor quality cannot strengthen the negative relationship between liquidity and the risk of financial statements fraud.

Thus, the results reveal that the coefficient of determination analysis shows that auditor quality is used as a moderating variable has proven to further improve the regression model. The effect of financial ratios on profitability, leverage, and liquidity is shown to represent $4.7 \%$ of the risk of financial statements fraud. The addition of auditor quality as an independent variable is shown to illustrate $7.9 \%$ of the risk of financial statements fraud. Incorporating auditor quality as a moderating variable is proven to improve the regression model by describing $11 \%$ of the risk of financial statements fraud actions so that $89 \%$ comes from outside the research model.

\section{Results and Discussion}

Based on the results of statistical testing, there is a rejection of hypothesis 1 , thus proving that profitability does not negatively affect the risk of financial statements fraud. These results did not according to the fraud triangle theory and not agreement with other studies by Zainudin and Hashim (2016) in Malaysia for the period 2007 to 2013, and research by Lisic, et al. (2014) in China. However, the results of this study prove that there is a positive effect of profitability on the risk of financial statements fraud, which is an agreement by Repousis (2016) research in Greece which shows that profitability is positively related to financial statements fraud. These results showed the manufacturing companies in Indonesia for the period 2016 to 2017 , the higher profitability of the company which following the higher risk of financial statements fraud. This result should be a concern for regulators to increase supervision when the company increased profitability, especially with suspicious conditions. The test results in hypothesis 4 a prove that good quality auditors will suppress financial statements fraud. This result becomes the good news for the company because by using a qualified auditor it will provide a positive signal for the company to investors since it is proven to minimize the risk of financial statements fraud.

The regression test results also proved that leverage does not have a positive effect on the risk of financial statements fraud, and the quality of the auditor is not able to reduce the positive relationship of leverage against the risk of financial statements fraud. This result certainly not agrees with the fraud triangle theory and previous research, by Dalnial, et al. (2014a, 2014b), Aghghaleh, et al. (2013), and Dani, et al. (2013) in Malaysia. However, this result is in line with Repousis (2016) research in Greece, Nia (2015) on the Tehran Stock Exchange, Manurung and Hardika (2015) on the Indonesia Stock Exchange, Lisic, et al. (2014) in China, and Manurung and Hadian (2013) in Indonesia in 45 of the most liquid companies in Indonesia. These results corroborate previous research in Indonesia both from the research of Manurung and Hardika (2015) and Manurung and Hadian (2013) that in Indonesia the level of leverage has no effect on financial statements fraud, and the quality of auditors is unable to strengthen these negative relationships.

The results of liquidity testing prove that liquidity has a negative effect on the risk of financial statements fraud, but the auditor's quality is not proven to weaken the negative relationship of liquidity to financial statements fraud. According to the fraud triangle theory with the lower value of liquidity ratio, the company 
will increase more pressure so that was increased gradually the possibility of financial statements fraud and this result based on the previous researches by Zainudin and Hashim (2016), and Arshad, et al. (2015) in Malaysia. This result provides information that investors in manufacturing companies in Indonesia were very concerned about the company's liquidity because the company's liquidity is related to the company's ability to fulfill its short-term obligations. If manufacturing companies in Indonesia increasingly experience liquidity problems, it becomes a negative signal for investors and creditors, because they are unable to fulfill their obligations. Thus, the company will do various ways to make the value of its current assets higher than its current liabilities, including by committing financial statements fraud. This result is an input for regulators to be more concerned about the condition of companies that have problems in their liquidity. The quality of auditors at this time is also not proven to be effective in dealing with this problem, because companies will experience more pressure that requires them to take action to save the company. This is evidenced by several cases in Indonesia such as the case of SNP Finance in 2018 which allegedly had carried out financial accounting bookkeeping engineering (Praditya, 2019), and in that year also PT Tirta Amarta Bottling on the indictment of the Public Prosecutor (JPU) for falsifying the report finance (Sutriyanto, 2019), this action is carried out as an effort to save the company.

\section{Conclusions}

Research conducted on manufacturing companies in Indonesia for the period 2016-2017 shows the results that the financial statements fraud risk is influenced by financial liquidity ratios, while financial ratios of profitability and leverage have not been proven to affect financial report fraud. This study provides a contribution by providing evidence that the quality of auditors can suppress financial statements fraud when profitability is low, while auditor quality has no effect when moderating the relationship of leverage and liquidity to the risk of financial statements fraud. This study also provides input that an interesting phenomenon in Indonesia is that profitability is positively related to the risk of financial statements fraud in the order it contradicts with the fraud triangle theory and in the future, it is expected that further research can examine more deeply why this phenomenon occurred in Indonesia. This research provides input to regulators to care more about companies that experience liquidity problems, because the risk of fraud is higher, and regulators can increasingly make rules to improve auditor quality because auditor quality is proven to weaken financial statements fraud.

\section{References}

Aghghaleh, S.F., Iskandar, T.M., \& Mohamed, Z.M. (2013). Fraud Risk Factors of Fraud Triangle and the Likelihood of Fraud Occurrence: Evidence from Malaysia. Proceedings of 4th International Conference on Education and Information Management (ICEIM), 25-29.

Aghghaleh, S.F., Mohamed, Z.M., \& Rahmat, M.M. (2016). Detecting Financial Statement Frauds in Malaysia: Comparing the Abilities of Beneish and Dechow Models. Asian Journal of Accounting and Governance. 7, 57-65.

Amoa-Gyarteng, K. (2014). Analyzing a Listed Firm in Ghana for Early Warning Signs of Bankruptcy and Financial Statement Fraud: An Empirical Investigation of AngloGold Ashanti. European Journal of Business and Management, 6(5), 10-17. ISSN: 2222-1905.

Arshad, R., Iqbal, S.M., \& Omar, N. (2015). Prediction of Business Failure and Financial statements fraud ing: Evidence from Malaysia. Indian Journal of Corporate Governance, 8(1), 34-53, doi: 10.1177/0974686215574424.

Association of Certified Fraud Examiners. 2018. Report to the Nations 2018 Global Study on Occupational Fraud and Abus Asia-Pacific Edition.ACFE, from www.acfe.com.

Cressey. D.R. 1953. Other People's Money. Montclair, NJ: Patterson Smith. 
Dalnial, H., Kamaluddin, A., Sanusi, M.D., \& Khairuddin, K.S. (2014a, March). Detecting Financial statements fraud ing through Financial Statement Analysis. Journal of Advanced Management Science, 23(1), 17-22. doi: 10.12720/joams.

Dalnial, H., Kamaluddin, A., Sanusi, M.D., \& Khairuddin, K.S. (2014b). Accountability in financial reporting: detecting fraudulent firms. Procedia - Social and Behavioral Sciences, 145, 61 - 69.

Dani, R.M., Ismail, W.A.W., Kamarudin, K.A. (2013). Can Financial Ratio Explain The Occurrence of Financial statements fraud? The 5th International Conference on Financial Criminology (ICFC). 345-354.

Hung, N.D., Ha, H.T.V \& Binh D. T. (2017). Application of F-Score in Predicting Fraud, Errors: Experimental Research in Vietnam. International Journal of Accounting and Financial Reporting, 7(2), 303-322. https://doi.org/10.5296/ijafr.v7i2.12174.

Kanapickienè, R., \& Grundienè, Ž. (2015). The Model of Fraud Detection in Financial Statements by Means of Financial Ratios. Procedia - Social and Behavioral Sciences. 213, 32 -327.doi: 10.1016/j.sbspro.2015.11.545

Liana, L. (2009). Penggunaan MRA dengan Spss untuk Menguji Pengaruh Variabel Moderating terhadap Hubungan antara Variabel Independen dan Variabel Dependen. Jurnal Teknologi Informasi DINAMIK. 14(2), 90-97.

Lisic, L.L., Silveri, S., Song, Y., \& Wang, K. (2014). Accounting fraud, auditing, and the role of government sanctions in China, Journal of Business Research, 1-10. http://dx.doi.org/10.1016/ j.jbusres.2014.11.013

Manurung, D.T.H., \& Hadian, N. (2013, November). Detection Fraud of Financial Statement with Fraud Triangle, Proceedings of 23rd International Business Research Conference. Symposium, Marriott Hotel, Melbourne, Australia, ISBN:978-1-922069-36-8.

Manurung, D.T.H., \& Hardika, A.L. (2015, August). Analysis of factors that influence financial statement fraud in the perspective fraud diamond: Empirical study on banking companies listed on the Indonesia Stock The exchange year 2012 to 2014, International Conference on Accounting Studies (ICAS). Symposium, Johor Bahru, Johor, Malaysia.

Nia, S.H. (2015, March). Financial ratios between fraudulent and non-fraudulent firms: Evidence from Tehran Stock Exchange. Journal of Accounting and Taxation, 7(3), 38-44, doi: 10.5897/JAT2014.0166.

Omar, N.B., Shafie, N.A., \& Mohd-Sanusi, Z. (2014, April). Financial Statement Fraud: A Case Examination Using Beneish Model and Ratio Analysis. International Journal of Trade, Economics, and Finance, 5(2), 184-186.

Omoye, A.S., \& Eragbhe, E. (2014). Accounting ratios and false financial statements detection: evidence from Nigerian quoted companies. International Journal of Business and Social Science, 7(1), 206215.

Praditya,I.I. (2019, June 6). Terkuak SNP Finance Rekayasa Laporan Keuangan Buat Bobol 14 Bank. https://www.liputan6.com/bisnis/read/3653070/terkuak-snp-finance-rekayasa-laporan-keuanganbuat-bobol-14-bank.

Repousis, S. (2016). Using Beneish model to detect corporate financial statement fraud in Greece, Journal of Financial Crime, 23(4), 1063-1073, https://doi.org/10.1108/ JFC-11-2014-0055.

Salem, M.S.M. (2012). An Overview of Research on Auditor's Responsibility to Detect Fraud on Financial Statements. The Journal of Global Business Management, 8(2).228-219.

Sharma, V.D., \& Iselin, E.R. (2012). The Association between Audit Committee Multiple-Directorships, Tenure, and Financial Misstatements. Auditing: A Journal of Practice \& Theory, 31(3), 149-175. doi: 10.2308/ajpt-10290. 
Skousen, C.J., Smith, K.R., \& Wright, C.J. (2015). Detecting and predicting financial statement fraud: The effectiveness of the fraud triangle and SAS No. 99 In Corporate Governance and Firm Performance, Corporate Governance and Firm Performance Advances in Financial Economics, 13, 53-81.

Suryanto, T. (2016). Audit Delay and Its Implication for Financial statements fraud ing: A Study of Companies Listed in the Indonesian Stock Exchange. European Research Studies, 19(1), 18-31.

Sutriyanto, E. (2019, June 6). Sebelum Jadi Kasus Korupsi Rp 1,8 T, PT TAB Sempat Akan Diselamatkan Investor. http://www.tribunnews.com/regional/2018/10/ 17/sebelum-jadi-kasus-korupsi-rp-18-t-pttab-sempat-akan-diselamatkan-investor.

Van Horne, J.C. \& Warchowich, J.M. (2005). Prinsip-prinsip Manajemen Keuangan. Edisi Keduabelas. Jakarta: Salemba empat

Zainudin, E.F., \& Hashim, H.A. (2016). Detecting financial statements fraud ing using financial ratio. Journal of Financial Reporting and Accounting, 14(2), 266-278, https://doi.org/10.1108/JFRA-05-20150053. 